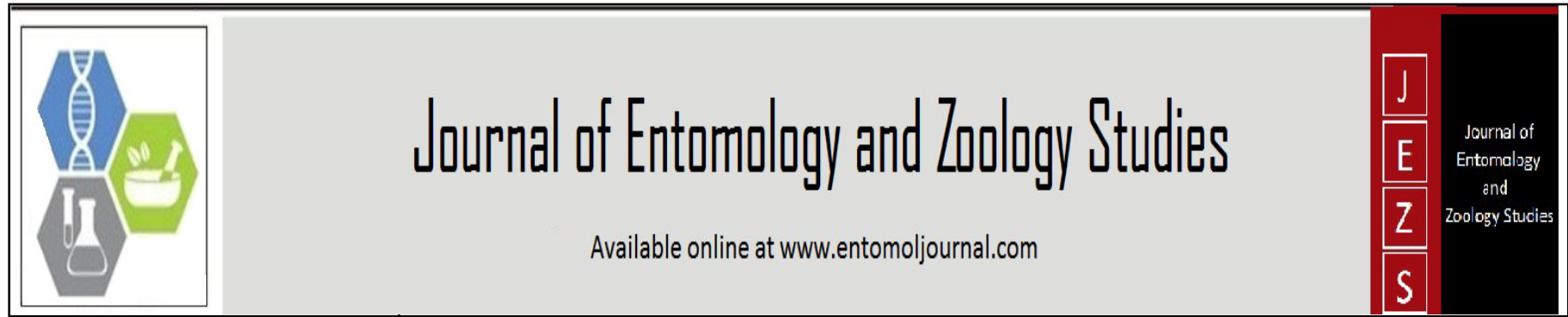

E-ISSN: 2320-7078

P-ISSN: 2349-6800

www.entomoljournal.com

JEZS 2021; 9(5): 14-23

(C) $2021 \mathrm{JEZS}$

Received: 05-06-2021

Accepted: 07-08-2021

\section{Chaker Bennour}

Arid Regions Institute, Douz

Road, Kebili. Tunisia

\section{Ali Ben Belgacem}

Arid Regions Institute, Douz

Road, Kebili. Tunisia

\section{Hammadi Hamza}

Arid Regions Institute, Douz

Road, Kebili. Tunisia

\section{Hmed Ben Nasr}

A) Arid Regions Institute, Douz

Road 4200. Kebili. Tunisia

B) Department of Life Sciences,

Faculty of Sciences of Gafsa.

Gafsa University Tozeur Road

2112 Gafsa. Tunisia.
Corresponding Author:

Chaker Bennour

Arid Regions Institute, Douz

Road, Kebili. Tunisia

\section{A review of the management of Tuta absoluta (Meyrick) (Lepidoptera: Gelechiidae) with special reference to biological control using plant extracts}

\author{
Chaker Bennour, Ali Ben Belgacem, Hammadi Hamza and Hmed Ben \\ Nasr
}

DOI: https://doi.org/10.22271/j.ento.2021.v9.i5a.8822

\section{Abstract}

The tomato leaf miner Tuta absoluta is one of the most destructive pests of tomato plant Solanum lycopersicum L worldwide. Synthetic chemical insecticides are mainly used to manage T. absoluta. However, their excessive use has led to serious problems concerning human health, non-target organisms and environnement. Biological control, using bacteria, entomopathogenic fungi, animals and plants remain an eco-friendly alternative for controlling the tomato leaf miner. Here we review the use of biological management of $T$. absoluta with special reference to control using plant extracts.

Keywords: Tuta absoluta, tomato, biological control, plant extracts.

\section{Introduction}

The tomato leaf miner or tomato borer or the South American tomato pinworm Tuta absoluta (Meyrick) (Lepidoptera: Gelechiidae) is one of the most damaging pests in many countries in America, Europe, Africa, and Asia ${ }^{[1]}$. In the last decade, this insect infested $60 \%$ of the tomato crops in many areas of the world. T. absoluta is a moltivoltine species. It parasitizes several cultivated and non-cultivated host plants belonging to Solanaceae, Amaranthaceae, Euphorbiaceae, Cucurbitaceae, Geraniaceae, Fabaceae, Asteraceae and Malvaceae ${ }^{\text {[2]. Its }}$ presence relies on environnmental conditions. Its development time is shorter at $28^{\circ} \mathrm{C}$ and 52 or $72 \%$ relative humidity ${ }^{[3]}$. Eggs are laid on leaves, stems and fruits ${ }^{[4]}$. Larvaes feed and devolop on leaves, fruits, flowers, buds and young shoots creating mines and galleries ${ }^{[5]}$.

The primary method to manage the pest is chemical control using synthetic insecticides ${ }^{[6,7,8]}$. These insecticides belong to several chemical groups: benzoylurea, spinosyn, pyrethroid, oxadiazine, diacylhydrazine, avermectin, ryanoid. Insecticides have many effects such as neurotoxicity, growth inhibition ${ }^{[9]}$. However, this method has multiple drawbacks like destruction of non-target organisms ${ }^{[10]}$, effects on human health and environnement contamination, insecticide resistance, reduced profit due to high synthetic pesticides costs ${ }^{[7]}$. In recent years, an increasing interest in using biological control including animals, entomopathogenic fungy and bioinsecticides has been noted. The aim of this paper is to list biological methods used to control T. absoluta with special reference to plant extracts.

\section{Taxonomy, origin and distribution of T. absoluta}

Tuta absoluta was first reported as Phthorimaea absoluta (Meyrick, 1917) in Peruvian Andes. The genus was changed to Gnorimoschema then to Scrobipalpula and Scrobipalpuloides. This insect was named Tuta absoluta by Povolny in $1994{ }^{[11]}$. However, in a recent study based on parcimony analysis, T. absoluta was classified in a monophyletic clade that included Phthorimaea operculella (Zeller, 1873), and Phthorimaea robusta and proposed the reinstated combination Phthorimaea absoluta (Meyrick, 1917) and a new combination Phthorimaea chiquitella (Busck, 1910) ${ }^{[12]}$.

Originated in South America, the tomato leaf miner was first introduced accidentally in Spain 2006 from where it spread to other countries in Europe, Africa and Asia ${ }^{[13]}$. 


\section{Biology of T. absoluta}

T. absoluta has a life cycle of four stages: the egg, the larvae, the pupa and adult (Fig 1). A sexual dimorphism is noted in $T$. absoluta from pupae stage. Indeed, female pupae can be distinguishable by two small tubercles present on the eighth abdominal segment. Also, female pupae and adults are heavier and bigger than males ${ }^{[4]}$.

Temperature, relative humidity and hostplant are the most important factors that affect the tomato leaf miner life cycle [3]. Adults are nocturnal. During the day, they hide between host leaves ${ }^{[11]}$ or on the tarpaulin of the greenhouse. A couple a days after emergence, female release sex pheromones; a mix of tetradecatrienyl acetate (90\%) and tetradecadienyl acetate (10\%) to attract male for mating ${ }^{[14,15]}$. In T.absoluta, the mechanism of reproduction involves either sexual reproduction and deuterotoky parthenogenetic process in which males and females are produced ${ }^{[16]}$. Fecundity was highest at $28^{\circ} \mathrm{C}$ and $52 \%$ relative humidity ${ }^{[3]}$.

The life cycle of the tomato leaf miner is characterized by the following traits ${ }^{[17]}$ :

- Oviposition can take place on leaves, veins, stems, sepals and fruits. A female can lay around 260 eggs during its life cycle. Eggs deposited are oval-cylindrical $(0.4 \mathrm{~mm}$ length; $0.2 \mathrm{~mm}$ diamter), hatch in about 7 days,

- Larvae stage lasts 8 days and there are four instars

- Pupa stage lasts 10 days: pupa are brown (4.3 mm in length and $1.1 \mathrm{~mm}$ in width).

- $\quad$ Adult stage: female lives 10-15 days and male lives 6-7 days.

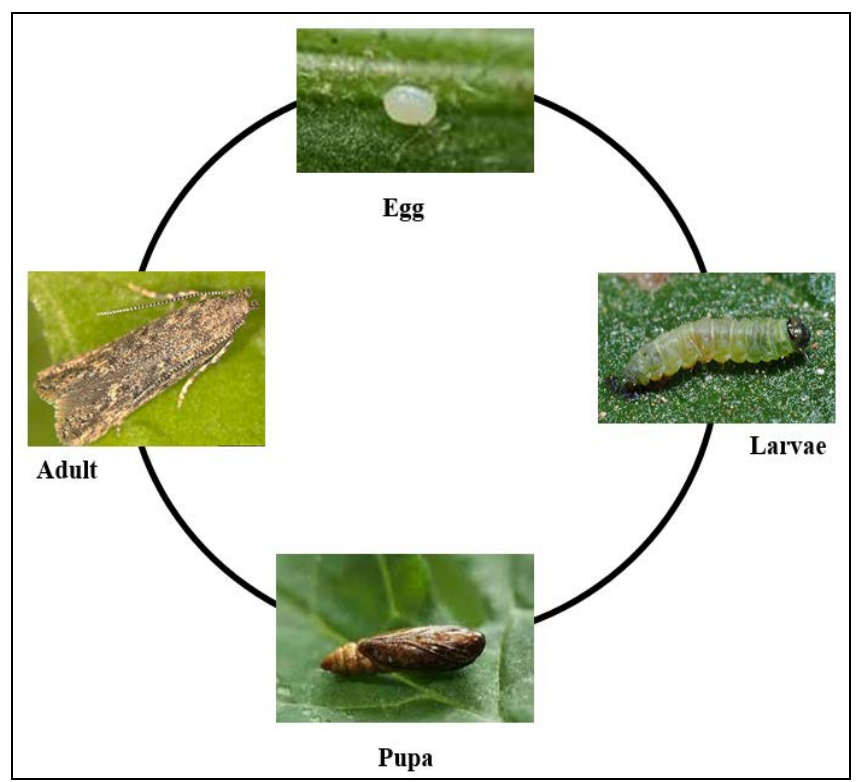

Fig 1: Life cycle of T. absoluta

\section{Damages and losses caused by $T$. absoluta}

The preferred host plant for T. absoluta feeding, oviopsition and growth is tomato. Larvae consumes leaf mesophyll and can induce two types of damages. Direct damages are related to the reduction of plants photosynthetic capacity and their production levels in consequence. Indirect damages are related to secondary infections due to pathogens developing on the injured plant and fruit tissues ${ }^{[13]}$. The tomato leaf miner can reduce the totality of tomato yield if no control is taken ${ }^{[6]}$. Damages caused by $T$. absoluta are summed up in reduced production, additional management costs and decreased and/or restricted trade ${ }^{[18]}$.

\section{Control and management of $T$. absoluta}

Some cultural control measures have been taken (crop rotation, selective removal, destruction of parasitised plants) ${ }^{[19]}$. However, the main strategy used to manage T. absoluta is chemical insecticides. Nevertheless, the effeciency of this method remains low because of the protection of the larvae in leaf mesolphyll or in fruit ${ }^{[20]}$ and its resistance to several chemical pesticides $[9,21]$. In order to decrease synthetic chemical insecticides, many strategies are used including pheromones and biological control.

\section{Pheromones based control}

Pheromones based strategies include pest detection, population monitoring, mass annihilation and mating disruption techniques ${ }^{[22]}$. A quantity of both T. absoluta pheromones on pheromone lures coupled with traps are used for the pest monitoring. Traps with dark colors seem to be more effective in catching males ${ }^{[23]}$. The placement of a trap is related to its height, its position with respect to vegetation and its density ${ }^{[24]}$.

Mass annihilation consists in mass trapping or lure and kill techniques. This approach relies on the attraction of adults to a lure (semichemicals or a light source) combined to a largecapacity trap or a pesticide impregnated target (adhesive surface or water trap) ${ }^{[25]}$. For the management of the tomato borer, a matrix formulated with $0.3 \%$ sex pheromone and $3 \%$ cypermethrin is available ${ }^{[26]}$.

The mating disruption is a technique that aims to reduce the pest population by introducing synthetic female pheromone that confuses individuals and disrupts mating ${ }^{[20]}$. The same reference showed that tomato leaf miner can be managed by means of mating disruption if the treatments are carried out in greenhouses well isolated that prevent new adults from entering.

Traps with pheromones is an effective technique to catch adults of $T$. absoluta [27]. Nevertheless, parthenogenetic potentiel of the pest reduces the success of these strategies ${ }^{[16]}$. Also, using pheromone mediated management have some demerits such as its high costs and limited availability ${ }^{[28]}$.

\section{Bacteria and entomopathogenic fungi}

The most bacterial control agents used to manage T. absoluta is Bacillus thuringiensis, ${ }^{[29,30,31,32]}$ and Saccharopolyspora spinosa ${ }^{[33]}$. Also, several entomopathogenic fungi are used in the control of tomato leaf miner: Metarhizium anisopliae [34, ${ }^{35]}$; Beauveria bassiana ${ }^{[36,37,38]}$, Aspergillus oryzae ${ }^{[39]}$, Saria farinosa $^{[40]}$, Clonostachys sp ${ }^{[38]}$ and Purpureocillium lilacinum ${ }^{[40]}$. Nutrient exhaustion and toxicosis induced by fungi penetration leads to death of the insect ${ }^{[41]}$.

Despite merits of using bacteria and entomopathogenic fungi in the control of pests, they have some inconveniences like side effects on non-target organisms caused by Bacillus thuringiensis ${ }^{[42]}$, lenghy duration of fungi effect ${ }^{[41]}$ and the possibility of resistance of pests against microorganisms used [16].

\section{Animals}

71 species belonging to 24 families and 8 orders are identified as predators of $T$. absoluta ${ }^{[43]}$. The most studied are Nesidiocoris tenuis (Reuter), Macrolophus pygmaeus (Rambur), Podisus nigrispinus (Dallas), Dicyphus errans (Wolff) and Brachygastra lecheguana (Latreille). According to the same reference, the list of enemies of tomato leaf miner hold 102 parasitoids belonging to 11 families and 2 orders. 
The most studied are Trichogramma pretiosum Riley, Pseudapanteles (=Apanteles) dignus (Muesebeck), Neochrysocharis formosa (Westwood), Trichogramma sp. Westwood, Apanteles sp. Förster, Earinus sp. Wesmael, Dineulophus phthorimaeae de Santis, Goniozus nigrifemur Ashmead, Trichogramma achaeae Nagaraja \& Nagaratti and Necremnus artynes (Walker). 75\% parasitizes larvae. Also, some entomopathogenic nematodes are used in the control of T. absoluta ${ }^{[28]}$. The most used are Steinernema feltiae, Steinernema carpocapsae and Heterorhabditis bacteriophora $[44,45,46]$.

Using animals to control T. absoluta is a promising strategy. Although, it may have some drawbacks. Indeed, predators or parasitoids can be polyphagus and can attack non-target organisms. Also, introducing exotic species can induce a disorder of the environment. Furthemore, the cost of consevration, transport and release of animals may be high. Some studies using IPM combine the use of predators with biopesticides ${ }^{[47]}$.

\section{Biological control of $T$. absoluta using plant extracts}

Using plant-extracts remains a more eco-friendly approach than synthetic insecticides. Botanicals remain a viable option for sustainable T. absoluta control. Indeed, they are widely available, easy to applicate and have low costs ${ }^{[28]}$. Also, plant extracts have low effects on human health and the environnment. Several species are used in $T$. absoluta management. The most studied belong to Lilliaceae,
Meliaceae, Rutaceae and Lamiaceae. Several parts of the plant are used, in particular leaves, seeds and peels. Aqueous extracts, ethanolic extracts and essential oils are the most forms used. Larvae is the most stage targeted because it's the stage that causes the most important damages. Major components are probably responsible for the biological effects. Some examples are presented here.

Alkamides found in Acmella oleracea have a pungent effect and seem to affect the nervous system inducing uncoordinated muscular activity. Their toxic effect is due to the disturbition of the ongoing processes of hostolysis of pest tissues ${ }^{[48]}$.

Piperamides, often found in the genus Piper, have dual biological activity on insects, including neurotoxic effect inducing in larvae symptoms of lethargy and low mobility and lipid metabolism effects ${ }^{[49,50,51]}$.

Simmondsin, the major component of Simmondsia chinensis, exert its lethal effect by penetrating the intertugument of the insect and affecting nervous or respiratory system ${ }^{[52]}$. It may induce a degree of desiccation and impair some vital physiological functions ${ }^{[53]}$.

Some components like methyl eugenol present in Ocimum gratissimum and Ocimum kilimandscharicum inhibit the enzyme acetylcholinesterase which can eventually lead to paralysis in the pest ${ }^{[54]}$.

Botanicals effectiveness can be improved by nanoparticles that solve problems related to essential oil volatility, low water solubility and the tendency ${ }^{[55]}$.

Table 1: List of plants used to make botanicals used against Tuta absoluta.

\begin{tabular}{|c|c|c|c|c|c|c|}
\hline Species & \begin{tabular}{|c|} 
Extracted \\
organ
\end{tabular} & $\begin{array}{c}\text { Form of } \\
\text { extract }\end{array}$ & $\begin{array}{l}\text { Biomassy method and pest } \\
\text { developmental stage (in bold) }\end{array}$ & $\begin{array}{c}\text { Major } \\
\text { compenent }\end{array}$ & Results & Reference \\
\hline $\begin{array}{l}\text { Acmella oleracea } \\
\text { (Asteracea) }\end{array}$ & $\begin{array}{c}\text { Aerial } \\
\text { parts }\end{array}$ & $\begin{array}{c}\text { Hexane and } \\
\text { ethanol } \\
\text { extracts }\end{array}$ & $\begin{array}{c}0.5 \mu \mathrm{L} \text { of a solution of the extract are } \\
\text { applicated on second-instar larvae } \\
\text { placed in a Petri dish. After the } \\
\text { application, the insects were kept in } \\
\text { individual petri dishes containing } \\
\text { tomato leaflets. }\end{array}$ & \begin{tabular}{|c|} 
Alkamides: \\
$*$ Spilanthol, \\
$*(E)-N-$ \\
isobutylundeca- \\
2-en-8,10- \\
diynamide \\
$*(R, E)-N-(2-$ \\
methylbutyl)un \\
deca-2-en-8,10- \\
diynamide.
\end{tabular} & $\begin{array}{c}* \text { The hexane extract causes } \\
100.0 \%(N=60) \text { mortality in } T \text {. } \\
\text { absoluta at a concentration of } 10 \\
\mu \text { g of extract per mg of insect } \\
\text { after } 6 \mathrm{~h} \text { of exposure. } \\
\text { * The ethanol extract showed } \\
\text { high activity }(88.3 \% \text { mortality). } \\
\text { * Spilnathol is the most active } \\
\text { (LD50 = 0.13 } \mu \text { g mg- } 1) \text {. }\end{array}$ & [33] \\
\hline $\begin{array}{l}\text { Allium cepa L. } \\
\text { (Lilliaceae) }\end{array}$ & & $\begin{array}{l}\text { Aqueous } \\
\text { extract }\end{array}$ & $\begin{array}{l}\text { In laboratory, second-instar larvae } \\
\text { were transferred on uninfested } \\
\text { tomato leaves in a Petri-dish. } \\
\text { Tomato leaves were soaked in } \\
\text { extract solution then left to dry } \\
\text { before introducing to larvae. } \\
\text { A tomato green house plot was } \\
\text { treated with the extract at } \\
\text { concentration of } 6 \% \text {. } \\
\end{array}$ & & $\begin{array}{c}\text { In laboratory, after } 5 \text { days and at } \\
\text { concentration of } 6 \% \text {, extract } \\
\text { induces a mortality of } 80.2 \% \text {. } \\
\text { In greenhouse, after } 8 \text { days and } \\
\text { at oncentration of } 6 \% \text {, extract } \\
\text { induces a mortality of } 89.7 \% \text { of } \\
\text { larvae. }\end{array}$ & [56] \\
\hline $\begin{array}{l}\text { Allium sativum L. } \\
\quad \text { (Lilliaceae) }\end{array}$ & & $\begin{array}{l}\text { Aqueous } \\
\text { extract }\end{array}$ & $\begin{array}{l}\text { In laboratory, second-instar larvae } \\
\text { were transferred on uninfested } \\
\text { tomato leaves in a Petri-dish. } \\
\text { Tomato leaves were soaked in } \\
\text { extract solution then left to dry } \\
\text { before introducing to larvae. } \\
\text { A tomato green house plot was } \\
\text { treated with the extract at } \\
\text { concentration of } 6 \% \text {. }\end{array}$ & & $\begin{array}{c}\text { In laboratory, after } 5 \text { days and at } \\
\text { concentration of } 6 \% \text {, extract } \\
\text { induces a mortality of } 84.6 \% \text {. } \\
\text { In greenhouse, after } 8 \text { days and } \\
\text { at oncentration of } 6 \% \text {, extract } \\
\text { induces a mortality of } 82.7 \% \text { of } \\
\text { larvae. }\end{array}$ & [56] \\
\hline $\begin{array}{l}\text { Allium sativum } \\
\text { (Lilliaceae) }\end{array}$ & Bulbs & $\begin{array}{l}\text { Aquous } \\
\text { extract }\end{array}$ & \begin{tabular}{|c|} 
Tomato plants were sprayed with the \\
extract at $5 \mathrm{ml} / \mathrm{L}$ three times at two \\
week intervals. Reduction of total \\
number of mines induced by larvae \\
is calculated.
\end{tabular} & & $\begin{array}{c}\text { Extract induces a reduction of } \\
69.32 \% \text { (in 2011) and } 78.33 \% \\
\text { (in 2012) after the 3rd spray and } \\
\text { increased the yield of tomato. }\end{array}$ & [57] \\
\hline $\begin{array}{l}\text { Allium sativum } \\
\text { (Lilliaceae) }\end{array}$ & Cloves & $\begin{array}{l}\text { Aqueous } \\
\text { extracts }\end{array}$ & $\begin{array}{l}\text { In laboratory, plant crude extracts } \\
\text { were sprayed on larvae in the Petri }\end{array}$ & & \begin{tabular}{|c|} 
In laboratory, extract induces at \\
$10 \%$ a mortality of $95 \%$ in 120
\end{tabular} & [58] \\
\hline
\end{tabular}




\begin{tabular}{|c|c|c|c|c|c|c|}
\hline & & & $\begin{array}{l}\text { dish at several concentrations (50, } \\
75 \text {, and } 100 \mathrm{ml} / \mathrm{L}) \text {. } \\
\text { In glasshouse, tomato plants were } \\
\text { sprayed with plant insecticides at } \\
\text { different concentrations (50, 75, and } \\
100 \mathrm{ml} / \mathrm{L}) \text {. }\end{array}$ & & \begin{tabular}{|c|} 
hours \\
In glasshouse, its mean efficacy \\
at $10 \%$ is $59.92 \%$ after 7 days.
\end{tabular} & \\
\hline $\begin{array}{c}\text { Azadirachta indica } \\
\text { (Meliaceae) }\end{array}$ & Seeds & $\begin{array}{c}\text { Ethanolic } \\
\text { extract }\end{array}$ & $\begin{array}{c}\text { Eggs were prepared in Petri-dishes } \\
\text { and were topically treated with the } \\
\text { different concentrations of the } \\
\text { extract }(1000,500,250,125 \text { and } \\
62.5 \mathrm{mg} / \mathrm{L}) \text {. } \\
\text { Recently hatched larvae were placed } \\
\text { in Petri-dishes with tomato } \\
\text { leaf, previously immersed in the } \\
\text { extract at different concentrations } \\
(8000,6000,4000 \text { and } 2000 \text { mg/L). }\end{array}$ & & $\begin{array}{c}\text { *After } 4 \text { days, around } 25 \% \text { of } \\
\text { egg mortalities were obtained } \\
\text { with the different concentrations } \\
\text { *Larval mortalities ranging } \\
\text { between } 33-46.7 \% \text { were } \\
\text { obtained after } 24 \text { hours } \\
\text { *Higher larval mortalities, } \\
\text { up to } 100 \% \text {, were obtained after } \\
4 \text { days of treatments. }\end{array}$ & [59] \\
\hline $\begin{array}{c}\text { Azadirachta indica } \\
\text { (Meliaceae) }\end{array}$ & Seeds & $\begin{array}{l}\text { Aqueous } \\
\text { extract }\end{array}$ & \begin{tabular}{|c|} 
In laboratory, plant crude extracts \\
were sprayed on larvae in the Petri \\
dish at several concentrations (50, \\
75 , and $100 \mathrm{ml} / \mathrm{L})$. \\
In glasshouse, tomato plants were \\
sprayed with plant insecticides at \\
different concentrations (50, 75, and \\
$100 \mathrm{ml} / \mathrm{L})$.
\end{tabular} & & $\begin{array}{c}\text { Neem seed (A. indica) at } 10 \% \\
\text { induce a mortality of } 98.33 \% \text { in } \\
120 \text { hours. } \\
\text { In glasshouse, its mean efficacy } \\
\text { at } 10 \% \text { is } 66.54 \% \text { after } 7 \text { days. }\end{array}$ & [58] \\
\hline $\begin{array}{l}\text { Carum copticum } \\
\text { (Apiaceae) }\end{array}$ & Seeds & Essential oil & $\begin{array}{c}\text { Bioassay was done with early fourth } \\
\text { instar larvae. Initially, preliminary } \\
\text { tests determined the effective dose } \\
\text { ranges; of } 2,4,8,16 \text {, and } 32 \mathrm{~mL} / \mathrm{mL} \\
\text { of extract and thymol, and } 3,6,12 \text {, } \\
\text { 24, and } 48 \mathrm{~mL} / \mathrm{mL} \text { of } \text {-terpinene } \\
\text { and p-cymene; were used against the } \\
\text { larvae. The fresh tomato leaf discs } \\
\text { were prepared and immersed in } \\
\text { aforementioned concentrations of } \\
\text { essential oil and its constituents. } \\
\text { Fourth instar larvae were transferred } \\
\text { into each disc. } \\
\text { To determine extract and their } \\
\text { constituents effects on the } \\
\text { detoxifying enzymes and } \\
\text { acetylcholine esterase, samples were } \\
\text { prepared by homogenizing fourth- } \\
\text { instar larvae, in } 500 \text { mL phosphate } \\
\text { buffer. Then, the samples were } \\
\text { centrifuged and the supernatants } \\
\text { were used as the enzyme source. }\end{array}$ & $\begin{array}{l}\text { Thymol, g- } \\
\text { terpinene, and } \\
\text { p-cymene }\end{array}$ & 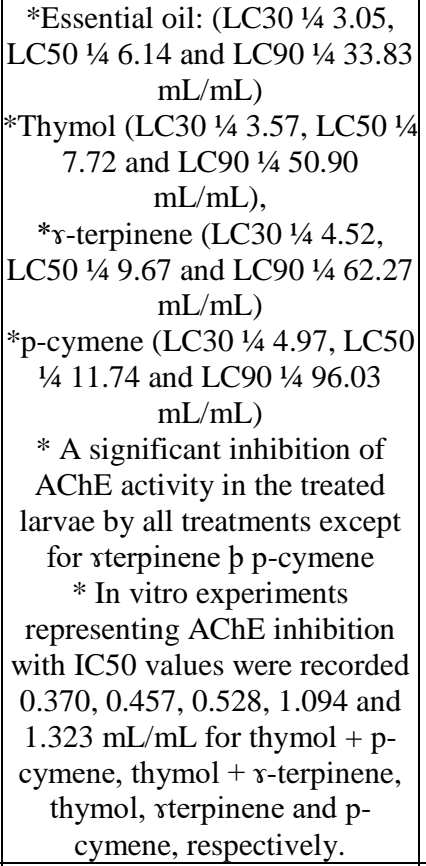 & [60] \\
\hline $\begin{array}{l}\text { Citrus aurantium } \\
\text { (Rutaceae) }\end{array}$ & Peels & Essential oil & \begin{tabular}{|} 
Filter papers were impregnated with \\
oil at fumigant concentrations of 5 to \\
$50 \mu \mathrm{l} / 1$ air and 25 to $200 \mu \mathrm{l} / 1$ air for \\
T. absoluta. Each impregnated filter \\
paper was attached to the screwcap \\
of a Plexiglas bottle. Larvae were \\
added to each bottle and caps were \\
screwed on tightly.
\end{tabular} & $\begin{array}{l}\text { Limonene } \\
(88.57 \%)\end{array}$ & $\begin{array}{l}\text { LC50 was } 14.68 \mu \mathrm{l} / 1 \text { air } \\
\text { LC90 was } 30.18 \mu \mathrm{l} / 1 \text { air }\end{array}$ & [61] \\
\hline $\begin{array}{l}\text { Citrus limon } \\
\text { (Rutaceae) }\end{array}$ & Peels & Essential oil & \begin{tabular}{|c|} 
Filter papers were impregnated with \\
oil at fumigant concentrations of 5 to \\
$50 \mu \mathrm{l} / \mathrm{l}$ air and 25 to $200 \mu \mathrm{l} / 1$ air for \\
T. absoluta. Each impregnated filter \\
paper was attached to the screwcap \\
of a Plexiglas bottle. Larvae were \\
added to each bottle and caps were \\
screwed on tightly.
\end{tabular} & $\begin{array}{l}\text { Limonene } \\
(70.46 \%)\end{array}$ & $\begin{array}{l}\text { LC50 was } 24.33 \mu \mathrm{l} / 1 \text { air } \\
\text { LC90 was } 39.2 \mu \mathrm{l} / 1 \text { air }\end{array}$ & [61] \\
\hline $\begin{array}{l}\text { Citrus limon } \\
\text { (Rutaceae) }\end{array}$ & Peels & Essential oil & $\begin{array}{c}* \text { Contact toxicity on eggs: tomato } \\
\text { plants were sprayed with the } \\
\text { formulations at concentrations }(2.5, \\
5,10,20 \text { and } 40 \mathrm{mg} \times \mathrm{mL}-1) \text {. After } \\
\text { drying } 10 \text { treated eggs were } \\
\text { transferred on the untreated and } \\
\text { islated tomato shoots. }\end{array}$ & $\begin{array}{l}\text { Limonene } \\
52.80 \%\end{array}$ & $\begin{array}{c}\text { After } 72 \mathrm{~h} \text {, at concentration } \\
40 \mathrm{mg} / \mathrm{ml} \text {, essential oil and } \\
\text { essential oil associated with } \\
\text { nanoparticules induce a } \\
\text { mortality of } \\
\bullet \quad 12 \% \text { of eggs. } \\
\bullet \quad 66 \% \text { and } 52 \% \text { of } \\
\end{array}$ & [62] \\
\hline
\end{tabular}




\begin{tabular}{|c|c|c|c|c|c|c|}
\hline & & & \begin{tabular}{|} 
*Translaminar toxicity on larvae: \\
second instar larvae were transferred \\
to untreated shoots and left to settle \\
until they entered the leaves. Then, \\
they were sprayed, dried and \\
isolated. \\
*Inegestion toxicity on larvae: \\
tomato plants were sprayed and left \\
to dry. shoots were collected and \\
individually isolated. Second instar \\
larvae were transferred to each \\
treated shoot.
\end{tabular} & & \begin{tabular}{|c|}
$\begin{array}{c}\text { larvae respectively for } \\
\text { translaminar toxicity } \\
\text { 30\% and } 40 \% \text { of } \\
\text { larvae respectively for } \\
\text { ingestion toxicity }\end{array}$ \\
For translaminar toxicity, LC50 \\
for essential oil and essential oil \\
associated with nanoparticle \\
equals 7.58 and $11.06 \mathrm{mg} / \mathrm{ml}$ \\
respectively \\
For ingestion toxicity, LC50 for \\
essential oil and essential oil \\
associated with nanoparticle \\
equals 111.04 and $47.4 \mathrm{mg} / \mathrm{ml}$ \\
respectively.
\end{tabular} & \\
\hline $\begin{array}{l}\text { Citrus reticulata } \\
\text { (Rutaceae) }\end{array}$ & Peels & Essential oil & $\begin{array}{c}\text { *Contact toxicity on eggs: tomato } \\
\text { plants were sprayed with the } \\
\text { formulations at concentrations ( } 2.5 \text {, } \\
5,10,20 \text { and } 40 \mathrm{mg} \times \mathrm{mL}-1) \text {. After } \\
\text { drying } 10 \text { treated eggs were } \\
\text { transferred on the untreated and } \\
\text { isolated tomato shoots. } \\
\text { *Translaminar toxicity on larvae: } \\
\text { second instar larvae were transferred } \\
\text { to untreated shoots and left to settle } \\
\text { until they entered the leaves. Then, } \\
\text { they were sprayed, dried and } \\
\text { isolated. } \\
\text { *Inegestion toxicity on larvae: } \\
\text { tomato plants were sprayed and left } \\
\text { to dry. shoots were collected and } \\
\text { individually isolated. Second instar } \\
\text { larvae were transferred to each } \\
\text { treated shoot. }\end{array}$ & $\begin{array}{c}\text { Limonene } \\
59.19 \%\end{array}$ & \begin{tabular}{|c|} 
After $72 \mathrm{~h}$, at concentration \\
40mg/ml, essential oil and \\
essential oil associated with \\
nanoparticles induce a mortality \\
of \\
22\% and 12\% of eggs \\
respectively. \\
78\% and 62\% of \\
larvae respectively for \\
translaminar toxicity \\
74\% and $86 \%$ of \\
larvae respectively for \\
ingestion toxicity \\
For translaminar toxicity, LC50 \\
for essential oil and essential oil \\
associated with nanoparticles \\
equals 6.45 and 23.09 mg/ml \\
respectively \\
For ingestion toxicity, LC50 for \\
essential oil and essential oil \\
associated with nanoparticle \\
equals 3.79 and 0.99 mg/ml \\
respectively.
\end{tabular} & [62] \\
\hline $\begin{array}{l}\text { Citrus sinensis L } \\
\quad \text { (Rutaceae) }\end{array}$ & Peels & Essential oil & $\begin{array}{c}\text { *Contact toxicity on eggs: tomato } \\
\text { plants were sprayed with the } \\
\text { formulations at concentrations ( } 2.5 \text {, } \\
5,10,20 \text { and } 40 \mathrm{mg} \times \mathrm{mL}-1) \text {. After } \\
\text { drying } 10 \text { treated eggs were } \\
\text { transferred on the untreated and } \\
\text { isolated tomato shoots. } \\
\text { *Translaminar toxicity on larvae: } \\
\text { second instar larvae were transferred } \\
\text { to untreated shoots and left to settle } \\
\text { until they entered the leaves. Then, } \\
\text { they were sprayed, dried and } \\
\text { isolated. } \\
\text { *Inegestion toxicity on larvae: } \\
\text { tomato plants were sprayed and left } \\
\text { to dry. shoots were collected and } \\
\text { individually isolated. Second instar } \\
\text { larvae were transferred to each } \\
\text { treated shoot. }\end{array}$ & $\begin{array}{c}\text { Limonene } \\
88.75 \%\end{array}$ & \begin{tabular}{|c|} 
After $72 \mathrm{~h}$, at concentration \\
40mg/ml, essential oil and \\
essential oil associated with \\
nanoparticles induce a mortality \\
of \\
92\% and 40\% of eggs \\
respectively. \\
80\% and 62\% of \\
larvae respectively \\
78\% and 62\% of \\
larvae respectively for \\
translaminar toxicity \\
50\% and $74 \%$ of \\
larvae respectively for \\
ingestion toxicity \\
For translaminar toxicity, LC50 \\
for essential oil and essential oil \\
associated with nanoparticles \\
equals 5.77 and 14.68 mg/ml \\
respectively \\
For ingestion toxicity, LC50 for \\
essential oil and essential oil \\
associated with nanoparticle \\
equals 8.9 and 1.53 mg/ml \\
respectively.
\end{tabular} & [62] \\
\hline $\begin{array}{c}\text { Cymbopogon } \\
\text { citratus (Poaceae) }\end{array}$ & Leaves & $\begin{array}{l}\text { Aqueous } \\
\text { extract }\end{array}$ & $\begin{array}{l}\text { In laboratory, plant crude extracts } \\
\text { were sprayed on larvae in the Petri } \\
\text { dish at several concentrations ( } 50 \text {, } \\
75 \text {, and } 100 \mathrm{ml} / \mathrm{L}) \text {. } \\
\text { In glasshouse, tomato plants were }\end{array}$ & & $\begin{array}{c}\text { Lemongrass (C. citratus) at } 10 \% \\
\text { induce a mortality of } 96.67 \% \text { in } \\
120 \text { hours } \\
\text { In glasshouse, its mean efficacy } \\
\text { at } 10 \% \text { is } 57.94 \% \text { after } 7 \text { days. }\end{array}$ & $\mid \begin{array}{c}\text { [58] Shiberu } \\
\text { \& Getu } \\
\text { (2017) }\end{array}$ \\
\hline
\end{tabular}




\begin{tabular}{|c|c|c|c|c|c|c|}
\hline & & & $\begin{array}{c}\text { sprayed with plant } \\
\text { insecticides at different } \\
\text { concentrations (50, 75, and } 100 \\
\mathrm{ml} / \mathrm{L}) \text {. }\end{array}$ & & & \\
\hline $\begin{array}{c}\text { Cymbopogon } \\
\text { citratus (Poaceae) }\end{array}$ & Leaves & $\begin{array}{l}\text { Aqueous } \\
\text { extract }\end{array}$ & $\begin{array}{c}\text { Tomato plants were sprayed with the } \\
\text { extract at } 5 \mathrm{ml} / \mathrm{L} \text { three times at two } \\
\text { week intervals. Reduction of total } \\
\text { number of mines induced by larvae } \\
\text { is calculated. }\end{array}$ & & $\begin{array}{l}\text { Extract induces a reduction of } \\
\text { 65.43\% (2011) and } 78.33 \\
\%(2012) \text { after the 3rd spray. }\end{array}$ & [57] \\
\hline $\begin{array}{l}\text { Eucalyptus } \\
\text { spp } \\
\text {.(Myrtaceae) }\end{array}$ & & Oil & $\begin{array}{l}\text { In laboratory, plant crude extracts } \\
\text { were sprayed on larvae in the Petri } \\
\text { dish at several concentrations ( } 50 \text {, } \\
\text { 75, and } 100 \mathrm{ml} / \mathrm{L} \text { ). } \\
\text { In glasshouse, tomato plants were } \\
\text { sprayed with plant } \\
\text { insecticides at different } \\
\text { concentrations }(50,75 \text {, and } 100 \\
\text { ml/L). }\end{array}$ & & $\begin{array}{l}\text { Oil induces a reduction of } \\
57.11 \%(2011) \text { and } 61.39 \% \\
\text { (2012) after the 3rd spray and } \\
\text { increased the yield of tomato. }\end{array}$ & [58] \\
\hline $\begin{array}{l}\text { Jatropha curcus } \\
\text { (Euphorbiaceae) }\end{array}$ & Seeds & $\begin{array}{c}\text { Petroleum } \\
\text { ether extract }\end{array}$ & $\begin{array}{c}\text { Eggs were prepared in Petri-dishes } \\
\text { and were topically treated with the } \\
\text { different concentrations of the } \\
\text { extract }(1000,500,250,125 \text { and } \\
62.5 \mathrm{mg} / \mathrm{L}) \text {. } \\
\text { Recently hatched larvae were placed } \\
\text { in Petri-dishes with tomato leaf, } \\
\text { previously immersed in the extract at } \\
\text { different concentrations }(8000,6000, \\
4000 \text { and } 2000 \mathrm{mg} / \mathrm{L}) \text {. }\end{array}$ & & $\begin{array}{c}\text { *After } 4 \text { days, around } 18 \% \text { of } \\
\text { egg mortalities were obtained } \\
\text { with the different concentrations } \\
\text { *Larval mortalities ranging } \\
\text { between } 23.5 \text { - } 48.5 \% \text { were } \\
\text { obtained after } 24 \text { hours. } \\
\text { *Higher larval mortalities, } \\
\text { up to } 100 \% \text {, were obtained after } \\
4 \text { days of treatments. }\end{array}$ & [59] \\
\hline $\begin{array}{c}\text { Melia azedarach L. } \\
\text { (Meliaceae) }\end{array}$ & $\begin{array}{c}\text { Leaves } \\
\text { and fruits }\end{array}$ & $\begin{array}{l}\text { Aqueous } \\
\text { extract }\end{array}$ & $\begin{array}{l}\text { In laboratory, second-instar larvae } \\
\text { were transferred on uninfested } \\
\text { tomato leaves in a Petri-dish. } \\
\text { Tomato leaves were soaked in } \\
\text { extract solution then left to dry } \\
\text { before introducing to larvae. } \\
\text { A tomato green house plot was } \\
\text { treated with the extract at } \\
\text { concentration of } 6 \% \text {. }\end{array}$ & & $\begin{array}{c}\text { In laboratory, after } 5 \text { days and at } \\
\text { concentration of } 6 \% \text {, leaves and } \\
\text { fruits extract induce a mortality } \\
\text { of } 91.2 \% \text {. } \\
\text { In greenhouse, after } 8 \text { days and } \\
\text { at oncentration of } 6 \% \text {, } \\
\text { *leaves extract induces a } \\
\text { mortality of } 74.0 \% \\
\text { * fruits extract induces a } \\
\text { mortality of } 60.7 \%\end{array}$ & [56] \\
\hline $\begin{array}{l}\text { Nicotiana species } \\
\text { (Solanaceae) }\end{array}$ & $\begin{array}{c}\text { Leaves } \\
\text { and stalks }\end{array}$ & $\begin{array}{l}\text { Aqueous } \\
\text { extract }\end{array}$ & $\begin{array}{l}\text { In laboratory, plant crude extracts } \\
\text { were sprayed on larvae in the Petri } \\
\text { dish at several concentrations ( } 50 \text {, } \\
\text { 75, and } 100 \mathrm{ml} / \mathrm{L}) \text {. } \\
\text { In glasshouse, tomato plants were } \\
\text { sprayed with plant } \\
\text { insecticides at different } \\
\text { concentrations ( } 50,75 \text {, and } 100 \\
\text { ml/L). }\end{array}$ & & $\begin{array}{c}\text { Tobacco (Nicotiana species) at } \\
10 \% \text { induces a mortality of } 80 \% \\
\text { in } 120 \text { hours. } \\
\text { In glasshouse, its mean efficacy } \\
\text { at } 10 \% \text { is } 62.10 \% \text { after } 7 \text { days. }\end{array}$ & [58] \\
\hline $\begin{array}{c}\text { Ocimum basilicum } \\
\text { L. } \\
\text { (Lamiaceae) }\end{array}$ & $\begin{array}{c}\text { Leaves } \\
\text { and flowrs }\end{array}$ & $\begin{array}{l}\text { Aqueous } \\
\text { extract }\end{array}$ & $\begin{array}{l}\text { In laboratory, second-instar larvae } \\
\text { were transferred on uninfested } \\
\text { tomato leaves in a Petri-dish. } \\
\text { Tomato leaves were soaked in } \\
\text { extract solution then left to dry } \\
\text { before introducing to larvae. } \\
\text { A tomato green house plot was } \\
\text { treated with the extract at } \\
\text { concentration of } 6 \% \text {. }\end{array}$ & & $\begin{array}{c}\text { In laboratory, after } 5 \text { days and at } \\
\text { concentration of } 6 \% \text {, } \\
\text { *leaves extract induces a } \\
\text { mortality of } 53.8 \% \\
\text { * flowers extract induces a } \\
\text { mortality of } 73.6 \% \\
\text { In greenhouse, after } 8 \text { days and } \\
\text { at oncentration of } 6 \%, \\
\text { *leaves extract induces a } \\
\text { mortality of } 84.7 \% \\
\text { * flowers extract induces a } \\
\text { mortality of } 87.0 \%\end{array}$ & [56] \\
\hline $\begin{array}{l}\text { Ocimum basilicum } \\
\text { (Lamiaceae) }\end{array}$ & & Oil & $\begin{array}{l}\text { In laboratory, plant crude extracts } \\
\text { were sprayed on larvae in the Petri } \\
\text { dish at several concentrations ( } 50 \text {, } \\
\text { 75, and } 100 \mathrm{ml} / \mathrm{L} \text { ). } \\
\text { In glasshouse, tomato plants were } \\
\text { sprayed with plant } \\
\text { insecticides at different } \\
\text { concentrations ( } 50,75 \text {, and } 100 \\
\text { ml/L). }\end{array}$ & & $\begin{array}{l}\text { Oil induces a reduction of } \\
67.97 \% \text { (2011) and } 72.78 \% \\
\text { (2012) after the 3rd spray. }\end{array}$ & [58] \\
\hline $\begin{array}{c}\text { Ocimum } \\
\text { gratissimum L. }\end{array}$ & $\begin{array}{c}\text { Aerial } \\
\text { parts }\end{array}$ & Essential oil & $\begin{array}{l}\text { *The repellent effect of the extract } \\
\text { and some of their constituents on }\end{array}$ & \begin{tabular}{|c|} 
Methyl eugenol \\
$(39.5 \%)$
\end{tabular} & $\begin{array}{c}\text { The repellence index at } 50 \% \text { was } \\
\text { RI50 }=0.13 \%\end{array}$ & [54] \\
\hline
\end{tabular}




\begin{tabular}{|c|c|c|c|c|c|c|}
\hline (Lamiaceae) & & & $\begin{array}{c}\text { adults was evaluated in a two choice } \\
\text { cuboidal plexi-glass wind tunnel at } \\
\text { several concentrations }(0.031,0.063 \text {, } \\
0.125,0.25,0.5 \text { and } 1 \mu \mathrm{l} / \mathrm{ml}) \text {. } \\
\text { *The toxic effect of exposing adults } \\
\text { to extract at different concentrations } \\
(0.031,0.063,0.125,0.25,0.5 \text { and } 1 \\
\mu 1 \mathrm{ml}-1) \text { of the oil and some of their } \\
\text { constituents is studied in small cage } \\
\text { chambers. }\end{array}$ & $\begin{array}{l}\text { Eugenol } \\
(29.7 \%)\end{array}$ & LC50 $=0.24$ and LC90 $=0.66$ & \\
\hline $\begin{array}{c}\text { Ocimum } \\
\text { kilimandscharicum } \\
\text { Gürke (Lamiaceae) }\end{array}$ & $\begin{array}{l}\text { Aerial } \\
\text { parts }\end{array}$ & Essential oil & $\begin{array}{c}\text { *The repellent effect of the extract } \\
\text { and some of their constituents on } \\
\text { adults was evaluated in a two choice } \\
\text { cuboidal plexi-glass wind tunnel at } \\
\text { several concentrations }(0.031,0.063 \text {, } \\
0.125,0.25,0.5 \text { and } 1 \mu \mathrm{l} / \mathrm{ml}) \text {. } \\
\text { *The toxic effect of exposing adults } \\
\text { to extract at different concentrations } \\
(0.031,0.063,0.125,0.25,0.5 \text { and } 1 \\
\mu 1 \text { ml-1) of the oil and some of their } \\
\text { constituents is studied in small cage } \\
\text { chambers. }\end{array}$ & $\begin{array}{l}\text { Camphor } \\
(47.0 \%), 1,8- \\
\text { Cineole } \\
(19.3 \%)\end{array}$ & $\begin{array}{l}\text { The repellence index at } 50 \% \text { was } \\
\qquad \mathrm{RI50}=0.5 \% \\
\mathrm{LC50}=0.43 \text { and } \mathrm{LC} 90=1.83\end{array}$ & [54] \\
\hline $\begin{array}{c}\text { Pelargonium zonale } \\
\text { (Geraniaceae) }\end{array}$ & & $\begin{array}{l}\text { Aqueous } \\
\text { extract }\end{array}$ & $\begin{array}{l}\text { In laboratory, second-instar larvae } \\
\text { were transferred on uninfested } \\
\text { tomato leaves in a Petri-dish. } \\
\text { Tomato leaves were soaked in } \\
\text { extract solution then left to dry } \\
\text { before introducing to larvae. } \\
\text { A tomato green house plot was } \\
\text { treated with the extract at } \\
\text { concentration of } 6 \% \text {. }\end{array}$ & & $\mid \begin{array}{c}\text { In laboratory, after } 5 \text { days and at } \\
\text { concentration of } 6 \% \text {, extract } \\
\text { induces a mortality of } 86.8 \% \text {. } \\
\text { In greenhouse, after } 8 \text { days and } \\
\text { at oncentration of } 6 \% \text {, extract } \\
\text { induces a mortality of } 53.0 \% \text {. }\end{array}$ & {$[56]$} \\
\hline $\begin{array}{c}\text { Phytolacca } \\
\text { dodecandra } \\
\text { (Phytolacaceae) }\end{array}$ & $\begin{array}{c}\text { Leaves } \\
\text { and seeds }\end{array}$ & $\begin{array}{l}\text { Aqueous } \\
\text { extract }\end{array}$ & $\begin{array}{c}\text { In laboratory, plant crude extracts } \\
\text { were sprayed on larvae in the Petri } \\
\text { dish at several concentrations (50, } \\
\text { 75, and } 100 \mathrm{ml} / \mathrm{L}) \text {. } \\
\text { In glasshouse, tomato plants were } \\
\text { sprayed with plant } \\
\text { insecticides at different } \\
\text { concentrations (50, 75, and } 100 \\
\mathrm{ml} / \mathrm{L}) \text {. }\end{array}$ & & $\begin{array}{c}\text { In laboratory, endod seed ( } P \text {. } \\
\text { dodecandra) at } 10 \% \text { induces a } \\
\text { mortality of } 56.67 \% \text { in } 120 \\
\text { hours. } \\
\text { In glasshouse, its mean efficacy } \\
\text { at } 10 \% \text { is } 36.51 \% \text { after } 7 \text { days. } \\
\text { Endod leaf ( } P \text {. dodecandra) at } \\
10 \% \text { induces a mortality of } 55 \% \\
\text { in } 120 \text { hours. } \\
\text { In glasshouse, its mean efficacy } \\
\text { at } 10 \% \text { is } 36.94 \% \text { after } 7 \text { days. }\end{array}$ & [58] \\
\hline $\begin{array}{c}\text { Pimpinella anisum } \\
\text { (Apiaceae) }\end{array}$ & & Oil & $\begin{array}{c}\text { In laboratory, plant crude extracts } \\
\text { were sprayed on larvae in the Petri } \\
\text { dish at several concentrations (50, } \\
\text { 75, and } 100 \mathrm{ml} / \mathrm{L}) \text {. } \\
\text { In glasshouse, tomato plants were } \\
\text { sprayed with plant } \\
\text { insecticides at different } \\
\text { concentrations (50, 75, and } 100 \\
\text { ml/L). }\end{array}$ & & $\begin{array}{c}\text { Oil induces a reduction of } \\
67.15 \%(2011) \text { and } 70 \%(2012) \\
\text { after the 3rd spray and increased } \\
\text { the yield of tomato. }\end{array}$ & [58] \\
\hline $\begin{array}{c}\text { Piper. amalago var. } \\
\text { medium, } \\
\text { Piper. glabratum, } \\
\text { Piper. mikanianum } \\
\text { (Piperaceae) }\end{array}$ & Leaves & $\begin{array}{l}\text { Ethanolic } \\
\text { extracts }\end{array}$ & $\begin{array}{c}\text { The extract was sprayed on tomato } \\
\text { leaves detached } \\
\text { from potted plants until the excess } \\
\text { started dripping off the leaves. After } \\
\text { drying the waste ( } 30 \text { min), the } \\
\text { leaflets were placed separately in } \\
\text { plastic Petri dishes and infested with } \\
\text { five newly-hatched larvae. }\end{array}$ & $\begin{array}{l}\text { Amides, } \\
\text { lignans, } \\
\text { alkaloids, and } \\
\text { neolignans }\end{array}$ & $\begin{array}{c}\text { Piper. amalago var. medium } \\
\text { induce a mortality of } 66.66 \% \text { in } \\
24 \text { hours } \\
\text { LC50 (95\%CI) in } 24 \\
\text { hours=1.008 } \\
\text { LC90 ( } 95 \% \text { CI) in } 24 \\
\text { hours=4.464 } \\
\text { Piper. Mikanianum induces a } \\
\text { mortality of } 50.47 \% \text { in } 24 \text { hours } \\
\text { Piper. Glabratum induces a } \\
\text { mortality of } 41.9 \% \text { in } 24 \text { hours } \\
\text { extracts caused a significant } \\
\text { reduction in the weight of the } \\
\text { surviving larvae by the sixth day } \\
\text { (144 hours) of exposure. } \\
\end{array}$ & [36] \\
\hline $\begin{array}{c}\text { Ricinus communis } \\
\text { (Euphorbiaceae) }\end{array}$ & Seeds & $\begin{array}{l}\text { Ethanol } \\
\text { extract }\end{array}$ & \begin{tabular}{|} 
Tomato leaves containing larvae \\
were dipped in 5 preparations of the \\
extract (1\%, $2 \%, 10 \%, 20 \%$ and \\
$100 \%)$ and then left to dry. The \\
leaves were then placed in a Petri
\end{tabular} & & $\begin{array}{c}\text { The extract nduces at } \\
\text { concentration of } 77500 \mathrm{mg} / \mathrm{l} \text { a } \\
\text { rate of mortality of } 58 \% \text { after } 72 \\
\text { hours. }\end{array}$ & [63] \\
\hline
\end{tabular}




\begin{tabular}{|c|c|c|c|c|c|c|}
\hline & & & dish containing agar. & & & \\
\hline $\begin{array}{l}\text { Ruta graveolens } \\
\text { (Rutaceae) }\end{array}$ & & Oil & $\begin{array}{l}\text { In laboratory, plant crude extracts } \\
\text { were sprayed on larvae in the Petri } \\
\text { dish at several concentrations ( } 50 \text {, } \\
75 \text {, and } 100 \mathrm{ml} / \mathrm{L}) \text {. } \\
\text { In glasshouse, tomato plants were } \\
\text { sprayed with plant } \\
\text { insecticides at different } \\
\text { concentrations (50, 75, and } 100 \\
\mathrm{ml} / \mathrm{L}) \text {. }\end{array}$ & & $\begin{array}{l}\text { Oil induces a reduction of } \\
65.36 \% \text { (2011) and 70.56\% } \\
\text { (2012) after the 3rd spray. }\end{array}$ & [58] \\
\hline $\begin{array}{c}\text { Simmondsia } \\
\text { chinensis } \\
\text { (Simmondsiaceae) }\end{array}$ & Seeds & $\begin{array}{c}\text { Simmondsin } \\
\text { extract by } \\
\text { ammonium } \\
\text { hydrogen } \\
\text { peroxide, } \\
\text { isopropanol, } \\
\text { acetone, or } \\
\text { water at } \\
\text { concentrations } \\
\text { of } 25,50,75 \\
\text { or } 100 \% \text {. }\end{array}$ & $\begin{array}{l}\text { Larvae (2nd larval instar) and tomato } \\
\text { leaves were put in Petri-dish and } \\
\text { were sprayed with a tested treatment } \\
\text { ( } 3 \mathrm{~mL} / \text { Petri-dish). }\end{array}$ & Simmondsin & $\begin{array}{l}\text { After } 7 \text { days inside tomato leaf } \\
\text { tunnel with topical application } \\
\text { and at conentration of } 100 \% \text {, } \\
\text { Simmondsin extract by } \\
\text { *ammonium hydrogen peroxide } \\
\text { induces a mortality of } 76.66 \% \text {. } \\
\text { * isopropanol induces a } \\
\text { mortality of } 76.66 \% \text {. } \\
\text { * acetone induces a mortality of } \\
96.66 \% \text {. } \\
\text { * water induces a mortality of } \\
95 \% \text {. }\end{array}$ & [38] \\
\hline $\begin{array}{l}\text { Thymus vulgaris } \\
\text { (Lamiaceae) }\end{array}$ & Leaves & $\begin{array}{l}\text { Ethanol } \\
\text { extract }\end{array}$ & \begin{tabular}{|} 
Tomato leaves containing larvae \\
were dipped in 5 preparations of the \\
extract (1\%, $\%$, 10\%, 20\% and \\
$100 \%)$ and then left to dry. The \\
leaves were then placed in a Petri \\
dish containing agar.
\end{tabular} & & $\begin{array}{c}\text { Induces at concentration of } \\
46667 \mathrm{mg} / \mathrm{l} \text { a rate of mortality of } \\
\text { 95\% after } 72 \text { hours } \\
\text { LD90 = 89383mg/l }\end{array}$ & [63] \\
\hline
\end{tabular}

\section{Conclusion}

Tuta absoluta is one of the most harmful insect pests of several cultivated and non-cultivated host plants, particularly tomato plant Solanum lycopersicum L. Chemical insecticides are mainly used to manage The tomato leaf miner. However, their excessive use has led to several problems. Biological managment remains an eco-friendly alternative for controlling of this pest. It relies on using bacteria, entomopathogenic fungi, animals and plants. Plant extracts are easy to applicate and have low costs. Several species, plant parts and extracts forms are used. Biological effects of these extracts are due probably to their major components that affect vital physiological functions such as neurophysiology and and respiration.

\section{Acknowledgement}

We are very grateful to $\mathrm{Mr}$ Abdeddeyem Boudhhir ("Higher Institute of Technological Studies of Djerba, Médenine”, Tunisia) for his kind help in English.

\section{References}

1. Santana PA, Kumar L, Da Silva RS, Picanço MC. Global geographic distribution of Tuta absoluta as affected by climate change. Journal of Pest Science 2019;92(4):13731385.

2. Cherif A, Verheggen F. A review of Tuta absoluta (Lepidoptera: Gelechiidae) host plants and their impact on management strategies. Biotechnologie, Agronomie, Société et Environnement 2019;23(4):270-278.

3. Cherif A, Attia-Barhoumi S, Mansour R, Zappalà L, Grissa-Lebdi K. Elucidating key biological parameters of Tuta absoluta on different host plants and under various temperature and relative humidity regimes. Entomologia Generalis 2019;39(1):1-7.

4. Genc H. The tomato leafminer, Tuta absoluta (Meyrick) (Lepidoptera: Gelechiidae): pupal key characters for sexing individuals. Turkish Journal of Zoology 2016;40(5):801-805.
5. Gebremariam G. Tuta absoluta: A global looming challenge in tomato production, Review Paper. Journal of Biology, agriculture and Healthcare 2015;5(14):57-62.

6. Biondi A, Guedes RNC, Wan FH, Desneux N. Ecology, worldwide spread, and management of the invasive South American tomato pinworm, Tuta absoluta: past, present, and future. Annual Review of Entomology 2018;63:239258.

7. Braham M, Glida-Gnidez H, Hajji L. Management of the tomato borer, Tuta absoluta in Tunisia with novel insecticides and plant extracts. EPPO bulletin 2012;42(2):291-296.

8. Mansour R, Brévault T, Chailleux A, Cherif A, GrissaLebdi K, Haddi K, et al. Occurrence, biology, natural enemies and management of Tuta absoluta in Africa. Entomologia Generalis 2018;38:83-112.

9. Silva GA, Picanço MC, Bacci L, Crespo ALB, Rosado JF, Guedes RNC. Control failure likelihood and spatial dependence of insecticide resistance in the tomato pinworm, Tuta absoluta. Pest management science 2011;67(8):913-920.

10. Soares MA, Passos LC, Campos MR, Collares LJ, Desneux N, Carvalho GA. Side effects of insecticides commonly used against Tuta absoluta on the predator Macrolophus basicornis. Journal of Pest Science 2019b;92(4):1447-1456.

11. El-Shafie HAF. Tuta absoluta (Meyrick) (Lepidoptera: Gelechiidae): An Invasive Insect Pest Threatening the World Tomato Production. In Invasive SpeciesIntroduction Pathways, Economic Impact, and Possible Management Options. Intech Open 2020, 1-16.

12. Chang PEC, Metz MA. Classification of Tuta absoluta (Meyrick, 1917) (Lepidoptera: Gelechiidae: Gelechiinae: Gnorimoschemini) Based on Cladistic Analysis of Morphology. Proceedings of the Entomological Society of Washington 2021;123(1):41-54.

13. Garzia GT, Siscaro G, Biondi A, Zappalà L. Tuta absoluta, a South American pest of tomato now in the 
EPPO region: biology, distribution and damage. EPPO Bulletin 2012;42(2):205-210.

14. Attygalle AB, Jham GN, Svatoš A, Frighetto RT, Meinwald J, Vilela EF, et al. Microscale, random reduction: Application to the characterization of (3E, 8Z, 11Z)-3, 8, 11-tetradecatrienyl acetate, a new lepidopteran sex pheromone. Tetrahedron letters 1995;36(31):54715474.

15. Attygalle AB, Jham GN, Svatoš A, Frighetto RT, Ferrara FA, Vilela EF, et al. (3E, 8Z, 11Z)-3, 8, 11Tetradecatrienyl acetate, major sex pheromone component of the tomato pest Scrobipalpuloides absoluta (Lepidoptera: Gelechiidae). Bioorganic \& medicinal chemistry 1996;4(3):305-314.

16. Megido RC, Haubruge E, Verheggen FJ. First evidence of deuterotokous parthenogenesis in the tomato leafminer, Tuta absoluta (Meyrick) (Lepidoptera: Gelechiidae). Journal of Pest Science 2012;85(4):409412.

17. Muniappan R. Tuta absoluta: the tomato leafminer. Collaborative Research on Integrated Pest Management 2015. United State of America.

18. Han P, Bayram Y, Shaltiel-Harpaz L, Sohrabi F, Saji A, Esenali UT et al. Tuta absoluta continues to disperse in Asia: damage, ongoing management and future challenges. Journal of Pest Science 2019;92(4):13171327.

19. Korycinska A, Moran H. South American tomato moth: Tuta absoluta. South American tomato moth: Tuta absoluta. plant pest factsheet. Sand Hutton, York, UK: FERA 2009.

20. Cocco A, Deliperi S, Delrio G. Control of Tuta absoluta (Meyrick) (Lepidoptera: Gelechiidae) in greenhouse tomato crops using the mating disruption technique. Journal of Applied Entomology 2013;137(12):16-28.

21. Reyes M, Rocha K, Alarcón L, Siegwart M, Sauphanor B. Metabolic mechanisms involved in the resistance of field populations of Tuta absoluta (Meyrick) (Lepidoptera: Gelechiidae) to spinosad. Pesticide Biochemistry and Physiology 2012;102(1):45-50.

22. Megido RC, Haubruge E, Verheggen FJ. Pheromonebased management strategies to control the tomato leafminer, Tuta absoluta (Lepidoptera: Gelechiidae). A review. Biotechnologie, Agronomie, Société et Environnement 2013;17(3):475-482.

23. Uchoa-Fernandes MA, Vilela EF. Field trapping of the tomato worm, Scrobipalpuloides absoluta (Meyrick) (Lepidoptera: Gelechiidae) using virgin females. Anais da Sociedade Entomologica do Brasil 1994;23(2):271276.

24. Howse P, Stevens JM, Jones OT. Insect pheromones and their use in pest management. Springer Science \& Business Media. Chapman and Hall, London 1998, 369.

25. Witzgall P, Kirsch P, Cork A. Sex pheromones and their impact on pest management. Journal of chemical ecology 2010;36(1):80-100.

26. Al Zaidi S. Managing Tuta absoluta by means of pheromones. Phytoma España (España) 2010;217:41.

27. Ettaib R, Belkadhi MS, Belgacem AB, Aoun F, Verheggen F, Megido RC. Effectiveness of pheromone traps against Tuta absoluta. Journal of Entomology and Zoology Studies 2016;4(6):841-844.

28. Tarusikirwa VL, Machekano H, Mutamiswa R,
Chidawanyika F, Nyamukondiwa C. Tuta absoluta (Meyrick) (Lepidoptera: Gelechiidae) on the "Offensive" in Africa: Prospects for Integrated Management Initiatives. Insects 2020;11(11):764.

29. González-Cabrera J, Mollá O, Montón H, Urbaneja A. Efficacy of Bacillus thuringiensis (Berliner) in controlling the tomato borer, Tuta absoluta (Meyrick) (Lepidoptera: Gelechiidae). BioControl 2011;56(1):7180.

30. Sabbour MM. Biocontrol of the tomato pinworm Tuta absoluta (Meyrick) (Lepidoptera: Gelechiidae) in Egypt. Middle East Journal of Agriculture Research 2014;3(3):499-503.

31. Sabbour MM, Nayera YS. Evaluations of three Bacillus thuringiensis against Tuta absoluta (Meyrick) (Lepidoptera: Gelechiidae) in Egypt. International Journal of Science and Research 2014;3(8):2067-2076.

32. Sarr OM, Bal AB, Fossati-Gaschignard O, Gauthier N. Effectiveness of two biopesticides against the invasive tomato pest Tuta absoluta. Entomologia Experimentalis et Applicata 2021.

33. Bratu E, Petcuci AM, Sovarel G. Efficacy of the product Spinosad an insecticide used in the control of tomato leafminer (Tuta absoluta-Meyrick, 1917). Bulletin University of Agricultural Sciences and Veterinary Medicine Horticulture 2015;72(1):209-210.

34. Akutse KS, Subramanian S, Khamis FM, Ekesi S, Mohamed SA. Entomopathogenic fungus isolates for adult Tuta absoluta (Lepidoptera: Gelechiidae) management and their compatibility with Tuta pheromone. Journal of Applied Entomology 2020;144(9):777-787.

35. Ndereyimana A, Nyalala S, Murerwa P, Gaidashova S. Field efficacy of entomopathogens and plant extracts on Tuta absoluta Meyrick (Lepidoptera: Gelechiidae) infesting tomato in Rwanda. Crop Protection 2020;134:105-183.

36. El-Ghany NMA, Abdel-Razek AS, Ebadah IM, Mahmoud YA. Evaluation of some microbial agents, natural and chemical compounds for controlling tomato leaf miner, Tuta absoluta (Meyrick) (Lepidoptera: Gelechiidae). Journal of Plant Protection Research 2016;56(4):372-379.

37. Silva ACL, Silva GA, Abib PHN, Carolino AT, Samuels RI. Endophytic colonization of tomato plants by the entomopathogenic fungus Beauveria bassiana for controlling the South American tomato pinworm, Tuta absoluta. CABI Agriculture and Bioscience 2020;1(1):19.

38. Mahmoud FM, Bendebbah R, Benssaci B, Toudji F, Tafifet L, Krimi Z. Entomopathogenic efficacy of the endophytic fungi: Clonostachys sp. and Beauveria bassiana on Tuta absoluta (Meyrick) (Lepidoptera: Gelechiidae) larvae under laboratory and greenhouse conditions. Egyptian Journal of Biological Pest Control 2021;31(1):1-6.

39. Zekeya N, Mtambo M, Ramasamy S, Chacha M, Ndakidemi PA, Mbega ER. First record of an entomopathogenic fungus of tomato leafminer, Tuta absoluta (Meyrick) in Tanzania. Biocontrol Science and Technology 2019;29(7):626-637.

40. Yüksel E, Açıkgöz Ç, Demirci F, Muștu M. Effects of the entomopathogenic fungi, Beauveria bassiana, Isaria farinosa and Purpureocillium lilacinum, on eggs of Tuta 
absoluta (Meyrick)(Lepidoptera: Gelechiidae). Türkiye Biyolojik Mücadele Dergisi 2017;8(1):39-47.

41. Sani I, Ismail SI, Abdullah S, Jalinas J, Jamian S, Saad N. A review of the biology and control of whitefly, Bemisia tabaci (Hemiptera: Aleyrodidae), with special reference to biological control using entomopathogenic fungi. Insects 2020;11(9):1-18.

42. Nazarpour L, Yarahmadi F, Saber M, Rajabpour A. Short and long term effects of some bio-insecticides on Tuta absoluta Meyrick (Lepidoptera: Gelechiidae) and its coexisting generalist predators in tomato fields. Journal of Crop Protection 2016;5(3):331-342.

43. Ferracini $\mathrm{C}$, Bueno VH, Dindo ML, Ingegno BL, Luna MG, Salas Gervassio NG, et al. Natural enemies of Tuta absoluta in the Mediterranean basin, Europe and South America. Biocontrol Science and Technology 2019;29(6):578-609.

44. Batalla-Carrera L, Morton A, García-del-Pino F. Efficacy of entomopathogenic nematodes against the tomato leafminer Tuta absoluta in laboratory and greenhouse conditions. BioControl 2010;55(4):523-530.

45. Jacobson R, Martin G. A potential role for entomopathogenic nematodes within IPM of Tuta absoluta (Meyrick) on organic tomato crops. A potential role for entomopathogenic nematodes within IPM of Tuta absoluta (Meyrick) on organic tomato crops 2011;68:7983.

46. Van Damme VM, Beck BK, Berckmoes E, Moerkens R, Wittemans L, De Vis $R$ et al. Efficacy of entomopathogenic nematodes against larvae of Tuta absoluta in the laboratory. Pest management science 2016;72(9):1702-1709.

47. Soares MA, Campos MR, Passos LC, Carvalho GA, Haro $\mathrm{MM}$, Lavoir AV, et al. Botanical insecticide and natural enemies: a potential combination for pest management against Tuta absoluta. Journal of Pest Science 2019;92(4):1433-1443.

48. Moreno SC, Carvalho GA, Picanço MC, Morais EG, Pereira RM. Bioactivity of compounds from Acmella oleracea against Tuta absoluta (Meyrick) (Lepidoptera: Gelechiidae) and selectivity to two non-target species. Pest Management Science 2012;68(3):386-393.

49. Dyer LA, Palmer AD. (Eds.). Piper: a model genus for studies of phytochemistry, ecology, and evolution. New York: Kluwer academic/Plenum publishers 2004, 117134.

50. Scott IM, Gagnon N, Lesage L, Philogene BJ. R, Arnason JT. Efficacy of botanical insecticides from Piper species (Piperaceae) extracts for control of European chafer (Coleoptera: Scarabaeidae). Journal of economic entomology 2005;98(3):845-855.

51. Brito EFD, Baldin ELL, Silva RDCM, Ribeiro LDP, Vendramim JD. Bioactivity of Piper extracts on Tuta absoluta (Lepidoptera: Gelechiidae) in tomato. Pesquisa Agropecuária Brasileira 2015;50(3):196-202.

52. Marie SS, Amr EM, Salem NY. Effect of some plant oils on biological, physiological and biochemical aspects of Spodoptera littoralis (Boisd.). Research journal of agriculture and biological sciences 2009;5(1):103-107.

53. Abdel-Baky NF, Al-Soqeer AA. Controlling the 2nd instar larvae of Tuta absoluta Meyrick (Lepidoptera: Gelechiidae) by simmondsin extracted from jojoba seeds in KSA. Journal of Entomology 2017;14(2):73-80.

54. Essoung FRE, Tadjong AT, Chhabra SC, Mohamed SA,
Hassanali A. Repellence and fumigant toxicity of essential oils of Ocimum gratissimum and Ocimum kilimandscharicum on Tuta absoluta (Lepidoptera: Gelechiidae). Environmental Science and Pollution Research 2020;27(30):37963-37976.

55. González JOW, Gutiérrez MM, Ferrero AA, Band BF. Essential oils nanoformulations for stored-product pest control-Characterization and biological properties. Chemosphere 2014;100:130-138.

56. Ghanim NM, Abdel Ghani SB. Controlling Tuta absoluta (Lepidoptera: Gelechiidae) and Aphis gossypii (Hemiptera: Aphididae) by aqueous plant extracts. Life Science Journal 2014;11(3):299-307.

57. Hussein NM, Hussein MI, Gadel Hak SH, Shaalan HS, Hammad MA. Effect of two plant extracts and four aromatic oils on Tuta absoluta population and productivity of tomato cultivar gold stone. Journal of Plant Protection and Pathology 2015;6(6):969-985.

58. Shiberu T, Getu E. Effects of crude extracts of medicinal plants in the management of Tuta absoluta (Meyrick) (Lepidoptera: Gelechiidae) under laboratory and glasshouse conditions in Ethiopia. Journal of Entomology and Nematology 2017;9(2):9-13.

59. Kona NEM, Taha AK, Mahmoud ME. Effects of botanical extracts of Neem (Azadirachta indica) and jatropha (Jatropha curcus) on eggs and larvae of tomato leaf miner, Tuta absoluta (Meyrick) (Lepidoptera: Gelechiidae). Persian Gulf Crop Protection 2014;3(3):4146.

60. Piri A, Sahebzadeh N, Zibaee A, Sendi JJ, Shamakhi L, Shahriari M. Toxicity and physiological effects of ajwain (Carum copticum, Apiaceae) essential oil and its major constituents against Tuta absoluta (Meyrick) (Lepidoptera: Gelechiidae). Chemosphere 2020;256:127103.

61. Zarrad K, Chaieb I, Tayeb W, Chraief I, Laarif A, Hammami M, et al. Bio-insecticidal potential of essential oils of two citrus species against two greenhouse pests Tuta absoluta Meyrick and Spodoptera littoralis Boisduval. Microbiologie et Hygiène Alimentaire 2013;25:84-88.

62. Campolo O, Cherif A, Ricupero M, Siscaro G, GrissaLebdi K, Russo A, et al. Citrus peel essential oil nanoformulations to control the tomato borer, Tuta absoluta: chemical properties and biological activity. Scientific reports 2017;7(1):1-10.

63. Nilahyane A, Bouharroud R, Hormatallah A, Taadaouit NA. Larvicidal effect of plant extracts on Tuta absoluta (Lepidoptera: Gelechiidae). IOBC-WRPS Bulletin 2012;80:305-310. 